\title{
Comparison of Candida tropicalis and Recombinant Escherichia coli BL21 (DE3) Expressed Enzyme Production for Bioconversion of Lignocellulosic Materials
}

\author{
Tan, J.W. ${ }^{1}$, Mariam-Aisha, F. ${ }^{2}$ and S. Neelam ${ }^{3}$ \\ ${ }^{1}$ School of Graduate Studies, Management and Science University, Shah Alam, Selangor \\ ${ }^{2}$ Research Management Centre, Management and Science University, Shah Alam, Selangor \\ ${ }^{3}$ Industrial Biotechnology Research Center, Sirim Bhd, Shah Alam, Selangor \\ *Corresponding author: music_jiewei@hotmail.my
}

\begin{abstract}
Lignocellulose is the most abundant renewable resource naturally available with great potential for bioconversion to value-added bio-products in this case from coconut husk to reducing sugars with bioconverting enzyme(s) from Candida tropicalis and Escherichia coli BL21(DE3). This study was to colometrically analyze the xylitol bioconversion and PAGE analysis expressed natively and recombinantly. Pretreated coconut husk (PC) and carboxymethylcellulose (CMC) were used as the carbon source in minimal media to monitor the enzymatic activity, reducing sugar and enzyme production. Enzymatic hydrolysis was facilitated through fermentation of different compartments of $C$. tropicalis and recombinant E.coli BL21(DE3) between 0 to 96 hours. After 2 hour of induction, recombinant E. coli BL21(DE3), $0.224 \mathrm{~g} / \mathrm{L}$ (IN) showed higher enzymatic activity than C. tropicalis, $0.181 \mathrm{~g} / \mathrm{L}$ (EX). Bands expressed extracellularly by $C$. tropicalis had an estimated molecular weight of $45 \mathrm{kDa}$ while recombinant $E$. coli BL21(DE3) was 7 $\mathrm{kDa}$. Mannitol dehydrogenase had the highest similarity to the expected peptide sequence through MALDITOF MS analysis. Recombinant strains are developed to obtain a higher enzymatic activity compare to the native one. Future studies on optimization of production media may be done.
\end{abstract}

Keywords: Lignocellulose, Candida tropicalis, recombinant Escherichia coli BL21(DE3), enzyme, BCA, DNS, SDS-PAGE, MALDI-TOF

Coconut (Cocos nucifera) is being used in a variety range mainly for its medicinal and nutritional values. Coconut husk composed of lignocellulosic materials and contributes about $35 \%$ of weight in coconut (Agustriyanto et al. 2012). Lignocellulose biomass is characterized as the most abundant renewable 
resources with great potential for bioconversion to value-added bio products (Pathak \& Chaudhary, 2013). Lignocellulose mainly composed of cellulose, hemicellulose and lignin (Muley \& Boldor, 2017). Most microscopic organisms have the capability in degrading lignocellulose biomass (Pathak \& Chaudhary, 2013). Yeast represent one of the oldest humanity's domesticated organisms and responsible for enjoyable production such as xylitol and sorbitol (McKelvey \& Murphy, 2011). Recombinant strains are developed to obtain higher yield of production ( $\mathrm{Li}$ et al. 2017) Microbial enzymes have gained an interest for the widespread uses in industries and medicine owing to their stability, catalytic activity and ease of production compared to plant and animal enzymes (Singh et al. 2016). Mass spectrometry, polyacrylamide gel electrophoresis (PAGE) and various types of colorimetric method and are used in characterisation of proteins (Insight, 2016). The study aims to address enzymes responsible for lignocellulosic natural biodegradation in vitro micro-reactors using lab conditions.

\section{MATERIALS AND METHODS}

\section{Microorganism and culture conditions}

Candida tropicalis ATCC 13803 was maintained on SDA.C agar while recombinant Escherichia coli BL21(DE3) was on NA with ampicillin at $4^{\circ} \mathrm{C}$. Working cultures of yeast strain were grown in SD (Synthetic Defined) minimal broth, incubated at $25^{\circ} \mathrm{C}$ for 5 to 7 days at $140 \mathrm{rpm}$ while recombinant strain were in NB with ampicillin, incubated at $37^{\circ} \mathrm{C}$ for 24 hours at $140 \mathrm{rpm}$. The cell optical density $\left(\mathrm{OD}_{600}\right)$ was standardized with a spectrophotometer at $600 \mathrm{~nm}$.

\section{Collection and Pretreatment of Coconut Husk (PC)}

Coconut husk were collected, left for air dried and reduced to powder form by blender. Coconut husk were pretreated using alkaline pretreatment method. $5 \mathrm{~g}$ of coconut husk were placed into $20 \%$ of 500 $\mathrm{mL} \mathrm{NaOH}$ solution for autoclaved purpose. The sample was then filtered and the filtrate was added gradually with $\mathrm{H}_{2} \mathrm{SO}_{4}$ until a sudden colour change was observed. Precipitated solution was brought to centrifugation and pellets were collected (Sangaran, 2014).

\section{Enzyme extraction}

The yeast and recombinant cells were frozen overnight before thawed. The cells were resuspended twice with lysis buffer; yeast (50 mM Tris- $\mathrm{HCl}$ and 1\% DMSO) and recombinant (25 mM Tris- $\mathrm{HCl}$ ). Yeast cells were added with approximately $0.8 \mathrm{~g}$ of sterilised $0.5 \mathrm{~mm}$ glass beads into lysis buffer containing a mixture of protease inhibitors ( $1 \mathrm{mM}$ phenylmethylsulfonyl fluoride (PMSF), $1 \mathrm{~g} / \mathrm{mL}$ leupeptin and $1 \mathrm{~g} /$ $\mathrm{mL}$ pepstatin A) while approximately $0.2 \mathrm{~g}$ of $0.5 \mathrm{~mm}$ sterilised glass beads were added to recombinant cells suspension. The yeast cells were vortexed for 3 to 5 times each for one minute, each time keeping the cells on ice for one minute between vortexes for about 30 minutes while the recombinant cells were vortexed for 20 seconds and each time keeping the cells on ice for one minute between vortexes for about 8 times. The glass beads were discarded and cells were brought for centrifugation at $4^{\circ} \mathrm{C}$. The confirmation of cell disruption was done using crystal violet staining and examination under microscope (Ramanan et al. 2008 and Joshi \& Jain, 2017). 


\section{Enzymatic activity and production of reducing sugar}

The yeast and recombinant cells were transferred into the PC production medium $(0.6 \mathrm{~g} / \mathrm{L}$ yeast extract, $1.0 \mathrm{~g} / \mathrm{L} \mathrm{K}_{2} \mathrm{HPO}_{4}, 1.0 \mathrm{~g} / \mathrm{L} \mathrm{NaNO}_{3}, 1.0 \mathrm{~g} / \mathrm{L} \mathrm{KCl}, 0.5 \mathrm{~g} / \mathrm{L} \mathrm{MgSO}_{4}$ containing $0.5 \mathrm{~g} / \mathrm{L}$ PC assole carbon source) to obtain the maximum amount of enzymatic activity. These cultures were incubated at $30^{\circ} \mathrm{C}$ for 0 to 96 hour with agitation at $140 \mathrm{rpm} .10 \mathrm{~mL}$ of PC production medium aliquots were drawn at 0,2 , $24,48,72$ and 96 hour and were centrifuged at $8000 \mathrm{rpm}$ for $15 \mathrm{mins}$ at $4^{\circ} \mathrm{C}$ to remove the yeast debris. To analyze the enzymatic activity and production of reducing sugar, $1 \mathrm{~mL}$ of 3,5-dinitrosalicyclic acid (DNS) was added to $1 \mathrm{~mL}$ of sample. The solutions were incubated in water bath at $90^{\circ} \mathrm{C}$ for $15 \mathrm{mins}$ and $350 \mu \mathrm{L}$ of Rochelle salt were added. The absorbance was measured at $575 \mathrm{~nm}$ (Sangaran, 2014 and Tamayo et al. 2016).

\section{Total Protein Determination}

Bicinchoninic acid (BCA) assay was used to determine the total protein concentration of each sample according to Smith et al, 1985 procedure.

\section{Enzyme Purification and SDS - PAGE}

Enzyme purification was performed by centrifugation at $8000 \mathrm{rpm}$ for $15 \mathrm{~min}$ followed by Diethylaminoethyl Sepharose (DEAE) anionic exchange chromatography. The crude enzymatic extract was applied to DEAE Sepharose Fast Flow (GE Healthcare) column, which was equilibrated with five column volumes, 40 $\mathrm{mL}$, of $20 \mathrm{mM}$ Tris $\mathrm{HCl}, \mathrm{pH}$ 8.0. The column was then eluted with a linear gradient of 0 to $0.6 \mathrm{M} \mathrm{NaCl}$ in $20 \mathrm{mM}$ Tris $\mathrm{HCl}$ buffer, $\mathrm{pH} 8.0$, at a flow rate of $1000 \mu \mathrm{L}$ per min. Enzyme impurity and purity was determined by SDS - PAGE under denaturing conditions. $12 \%$ of separating and 3\% stacking gels were prepared. Electrophoresis was performed at room temperature at a constant voltage of $200 \mathrm{~V}$. The gel was stained with Coomassie Blue R-250 gel staining solution and was destained overnight using water (Bollag \& Edelstein, 1991 and Tamayo et al. 2016).

\section{MALDI-TOF}

Each gel band from SDS-PAGE was sliced and sent for MALDI-TOF at Apical Scientific Sdn. Bhd. According to Apical Scientific, the protein samples were trypsin digested and peptides extracted according to standard techniques. Spectra were analysed to identify protein of interest using Mascot sequence matching software [Matrix Science] with MSPnr 100 Database, SwissProt Taxanomy.

\section{Statistical Analysis}

Statistical analysis was performed using One Way ANOVA test (SPSS version 22.0). Differences were considered statistically significant at $\mathrm{p}<0.05$.

\section{RESULTS AND DISCUSSION}

\section{Growth and Production of Protein}

From the time course study in shake culture, it was found that the enzyme production rate was increased 
with the increased in the fermentation duration and reached its maximum activity after 24 hours of incubation of native strains $(1440.66 \mu \mathrm{g} / \mathrm{mL}$ in PC while $1336.67 \mu \mathrm{g} / \mathrm{mL}$ in $\mathrm{CMC})$ and 48 hours for recombinant strains $(1550.53 \mu \mathrm{g} / \mathrm{mL}$ in $\mathrm{PC}$ while $1139.82 \mu \mathrm{g} / \mathrm{mL}$ in CMC) as shown in Fig. 1(A) and Fig. 1(B).
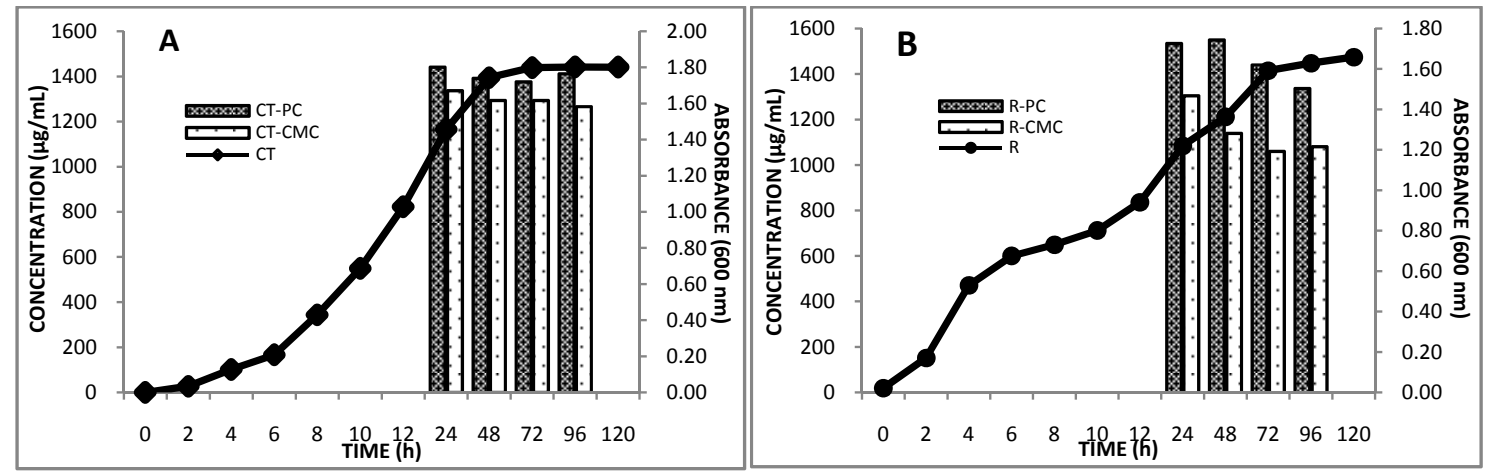

Fig. 1: Growth of native and recombinant strains with relation to its enzyme production. (A) Candida tropicalis (CT). (B) Recombinant Escherichia coli BL21(DE3) (R)

Tamayo et al. (2016), suggested that the enzymatic machinery of the yeast cells is complete at the highest point of growth and thus a greater amount of enzymes is produce. A prolonged incubation time beyond 24 hours for $C$. tropicalis and 48 hours for recombinant $E$. coli BL21(DE3) did not increased the enzyme production and this is due to the other by products accumulation in the media. Efficient induction occurred when stationary phase has been reached and the available carbon source was reduced (Deb et al. 2013). After an initial rapid phase of hydrolysis, the rate of hydrolysis will tend to decrease and entering the stationary phase. At this point, increasing the concentration of enzyme use may not result in higher degree of hydrolysis as the concentration of peptide bonds which available for the hydrolysis purposes may become a limiting factor (Enzim \& Ekstrak, 2013).

\section{Comparison of Protein Production to Sugar Production in Different Substrate}

PC showed higher protein and sugar production compare to CMC from both native and recombinant strains. Degradation of hemicellulose converts into potential saccharides which are mainly hydrolyzed by an array of interdependent and synergistic hemicellulases (Sweeney \& Xu, 2012). CMC contained higher degree of polymerization compared to coconut husk. Pure cellulose in CMC are linked by $\beta-1$, 4-glycosidic bonds that form the crystalline structure and highly organized microfibrils through extensive inter- and intra-molecular hydrogen bonds and Van der Waals forces (Nobre \& Aanen, 2012). During the pretreatment process, coconut husk had broken down into shorter chain compared to CMC which had a long backbone (Rosa \& Jorge, 2013). During the enzymatic hydrolysis, it is easier to hydrolyse the shorter chain in PC for the production of smaller and higher amount of reducing sugar compared to $\mathrm{CMC}$ due to the long chain and causes the decreased in production of reducing sugar (Kumari, 2013).

\section{Comparison of Native and Recombinant Expression Host of the Target Enzyme}

Enzymatic activity and production of reducing sugar were done using DNS assay. The presence of 
enzymatic activity indicates the formation of reducing sugar production. These reducing sugar were the intermediates for xylitol production. In Fig. 2, recombinant strains obtained a higher enzymatic rate compared to the native ones in PC which were $0.2243 \mathrm{~g} / \mathrm{L}$ and $0.1812 \mathrm{~g} / \mathrm{L}$ respectively $(\mathrm{p}<0.05)$. Native enzyme from yeast especially $C$. tropicalis is considered to be the best xylitol production primarily due to their high pentose assimilations rate and stable expression levels of the native enzymes. Native enzymes from yeast exhibit a good activity in degrading the stress and toxic substances and many small molecules impurities, which significantly improved the enzymatic activity and reducing sugar fermentation production performance and effectively reduces the burden of chemical and physical detoxification or purification processes (Dasgupta et al. 2017). The recombinant E. coli expression system is currently the most widely used system and it allows the expression of the targeted enzymes by different strategies. Therefore, in (pers. comm. Foo, 2019) studies, pGEM-T easy vector (expression plasmids) with T7 promoter were used for the cloning and expression of the enzyme. T7 promoter can effectively reduce the toxicity of basal expression for the host bacteria and hence effectively increase the expression level and enzymatic activity of the recombinant enzymes (Gao et al. 2015).

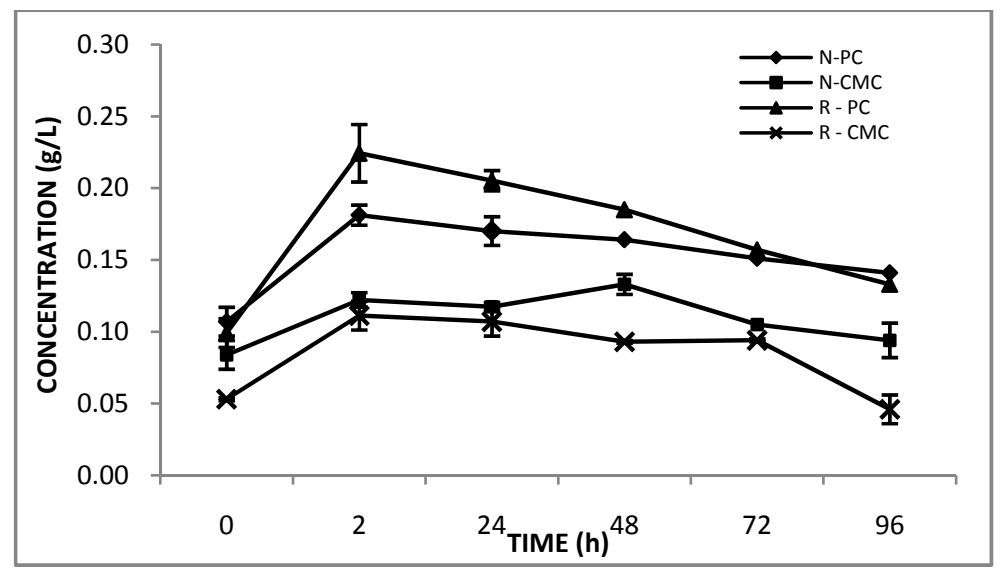

Fig. 2: Enzymatic activity and reducing sugar production of native $(\mathrm{N})$ extracellular $(\mathrm{EX})$ and recombinant (R) intracellular (IN) in PC and CMC minimal media at 0 to 96 hours

Xylitol is an extracellular metabolite. Due to the insolubility in lignocellulosic material, its degradation is occurred in the extracellular environment by native extracellular enzymes. The extracellular enzymes of the native strains had played an important part in hemicellulose degradation (Xie et al. 2016). The breakdown of hemicellulose requires the coordinated activity of a number of extracellular enzymes that function synergistically to hydrolyze the polysaccharides into small oligosaccharides and then finally it was converted into monomers. The complexity of these enzymatic systems is further increased due to the microorganisms were tend to produce different class modular enzyme for the improvement of the efficiency of the breakdown of complex and recalcitrant structure (Janusz et al. 2017). Recombinant enzymes are expressed intracellularly and were remained inside the cell due to the large size of the enzyme that they are unable to move across the membrane (Rosano, 2014). Enzyme secretion was improved by inducing the limited leakage of the outer membrane. Recombinant enzymes production may be facilitated by the introduction of the gene in an autonomously replicating plasmids or by integrating it to the genome (Liu et al. 2013). 
When compared to initial enzymatic activity at 0 hour, there was significance increased in enzyme activity in the case of as the time increased. Enzim \& Ekstrak, 2013, reported that when an enzyme is added into a substrate, enzymatic activity will start to occur in which the enzyme will be absorbed into the suspended particles, where the hydrolysis of the enzyme - susceptible peptide linkages will take place simultaneously. Averagely, the enzyme exhibited its maximum enzymatic activity at 2 hours of reaction time and after that the production decreased as the time increased. This is because it may due to the depletion of the carbon source or the reducing sugar had been used up for the bioconversion into bio-products such as xylitol with the aid of XR and XDH (Sarker et al. 2013).

\section{SDS-PAGE and probable results for MALDI-TOF}

The molecular weight and purity of purified enzyme were determined using denaturing PAGE. In Fig. 3(A), a single protein band was obtained by $0.2 \mathrm{M}$ and $0.3 \mathrm{M} \mathrm{NaCl}$ gradient after chromatography purification focusing with a relative mass of $45 \mathrm{kDa}$, which corresponds to the targeted enzyme from C. tropicalis. Similar $\beta$-1,3-glucanases were reported for yeast (48.3 kDa) by Tamayo et al. (2016). In Fig. 3(B), expected target protein band was expressed with a relative molecular weight (MW) of $7 \mathrm{kDa}$. Similar xylan 1,4- $\beta$-xylosidase (6894 Da) was reported for Enterococcus avium at SwissProt, 2019. There were no protein bands expressed by both native and recombinant strains in CMC production media.

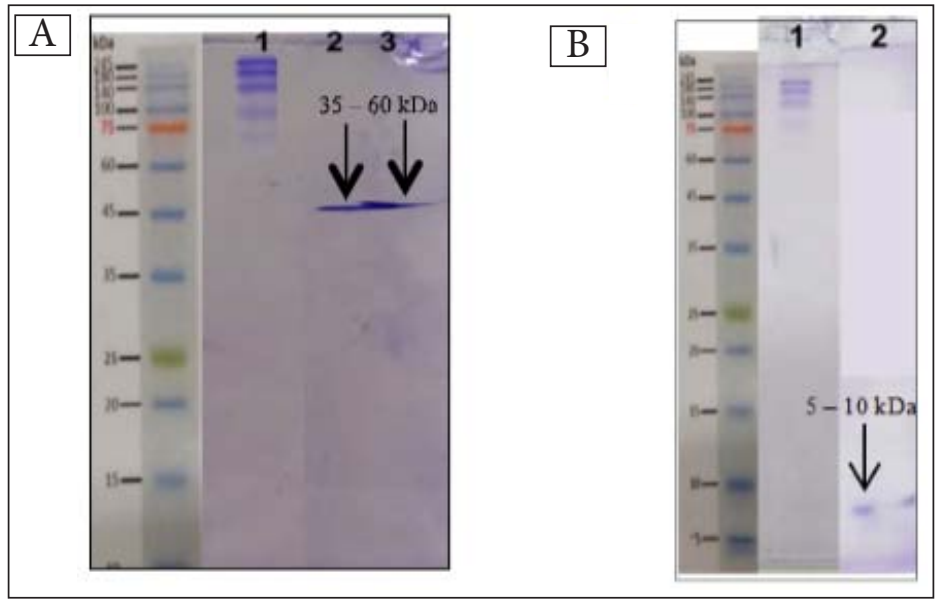

Fig. 3: (A) Purified single band was obtained at 0.2 (2) and $0.3 \mathrm{M}$ (3) $\mathrm{NaCl}$ gradient with $\mathrm{MW}$ between 35 to $60 \mathrm{kDa}$. (B) Single protein band (2) obtained with MW between 5 to $10 \mathrm{kDa}$

The identity of the targeted enzyme was done using MALDI-TOF MS analysis. The targeted enzyme does not hit the specific peptide sequence in which a different enzyme was observed. This may due to the protein have been degraded. Mannitol dehydrogenase (MDH) is one of the top hits which were similar to the targeted peptide sequence. MDH have an E.C. number of 1.1.1.255 and is belongs to the family of oxidoreductases. MDH have a molecular weight of $53 \mathrm{kDa}$. This enzyme reduces the D-mannitol into D-mannose (SwissProt, 2019). Mannose residues are connected by a $\beta$-1, 4-glycosidic bond to form the mannan for hemicellulose backbone. Mannose is the most important hemicellulosic monomer followed by xylose, glucose, galactose and arabinose. Mannoses reduced by MDH from mannitol were act as the carbon sources for the production of xylitol (Menon et al. 2013). Xylan 1, 4- $\beta$-xylosidase has an 
E.C number of 3.2.1.37 and this enzyme hydrolyse the (1->4)-beta-D-xylans to remove the successive D-xylose residues from the non-reducing terminal (SwissProt, 2019).

\section{CONCLUSION}

Recombinant $E$. coli BL21(DE3) showed higher enzyme production and enzymatic activity than $C$. tropicalis. Both microorganisms demonstrated significant $(\mathrm{p}<0.05)$, ability to convert and produce both PC and CMC to reducing sugar and enzymes. Enzyme bands had expressed extracellularly by $C$. tropicalis, mannitol dehydrogenase while recombinant $E$. coli BL21(DE3) had expressed intracellularly, xylan 1, 4- $\beta$-xylosidase. Recombinant strains are better in the degradation of lignocellulosic material to produce xylitol compare to the native one. Future studies on optimization of culture conditions and media components may be done.

\section{ACKNOWLEDGEMENTS}

The authors wish to acknowledge the Ministry of Education Malaysia for funding this research under the FRGS grant no. FRGS/2/2014/SG05/MSU/02/01.

\section{REFERENCES}

1. Agustriyanto, R., Fatmawati, A. and Liasari, Y. 2012. Study of enzymatic hydrolysis of dilute acid pretreated coconut husk. Bulletin of Chemical Reaction Engineering and Catalysis, 7(2): 137-141.

2. Bollag, D.M. and Edelstein, S.J. 1991. Protein methods. Isbn 0471568716. Retrieved from http://www. getcited.org/pub/102871194.

3. Dasgupta, D., Bandhu, S., Adhikari, D.K. and Ghosh, D. 2017. Challenges and prospects of xylitol production with whole cell bio-catalysis : A review. Microbiological Research, 197: 9-21.

4. Deb, P., Talukdar, S.A., Sarker, P.K. and Sayem, S.M.A. 2013. Production and partial characterization of extracellular amylase enzyme from Bacillus amyloliquefaciens P-001, (August 2015).

5. Enzim, K.K. and Ekstrak, H. 2013. Effects of Enzyme Concentration, Temperature, pH and Time on the Degree of Hydrolysis of Protein Extract from Viscera of Tuna (Euthynnus affinis) by Using Alcalase, 42(3): 279-287.

6. Foo, Y.H. 2019. Metabolic Engineering of lignocellulosic nzymes into a single construct for recombinant in situ bioconversion.

7. Gao, X., Yan, X. and Kang, Z. 2015. Purification, characterization, and heterologous expression of an antifungal protein from the endophytic Bacillus subtilis strain Em7 and its activity against Sclerotinia sclerotiorum, 1238189 (February 2016).

8. Insights, M. 2016. HHS Public Access, pp. 43-51.

9. Janusz, G., Pawlik, A., Sulej, J., Swiderska-burek, U., Jarosz-wilkołazka, A. and Paszczy, A. 2017. Lignin degradation : microorganisms, enzymes involved, genomes analysis and evolution, (October), pp. 941-962. 
10. Joshi, H. and Jain, V. 2017. Novel method to rapidly and efficiently lyse Escherichia coli for the isolation of recombinant protein. Analytical Biochemistry, 528: 1-6.

11. Kumari, M. 2013. Production of lignocellulose ethanol from Ipomoea carnes by bacterial cellulase of cow and deer dung. Life Science National Institute of Technology Rourkela, (411).

12. Li, Y., Gou, Z., Zhang, Y., Xia, Z., Tang, Y. and Kida, K. 2017. Biotechnology and Industrial Microbiology Inhibitor tolerance of a recombinant flocculating industrial Saccharomyces cerevisiae strain during glucose and xylose co-fermentation. Brazilian Journal of Microbiology, 48(4): 791-800.

13. Liu, L., Yang, H., Shin, H., Chen, R.R., Li, J., Du, G. and Chen, J. 2013. How to achieve high-level expression of microbial enzymes Strategies and perspectives. Landes Bioscience. Do not distribute, 4(4): 212-223.

14. McKelvey, S.M. and Murphy, R.A. 2011. Biotechnological Use of Fungal Enzymes. Fungi: Biology and Applications.

15. Menon, V., Prakash, G. and Rao, M. 2013. Value added products from hemicellulose : Biotechnological perspective Keywords.

16. Muley, P.D. and Boldor, D. 2017. Advances in Biomass Pretreatment and Cellulosic Bioethanol Production Using Microwave Heating, (June), 27-30.

17. Nobre, T. and Aanen, D.K. 2012. Fungi culture or termite husbandry? the ruminant hypothesis. Insects, 3(1): 307-323.

18. Pathak, S. and Chaudhary, H.S. 2013. Perspective of microbial species used in lignocelluloses bioconversion. International Journal of Pharma and Bio Sciences, 4(2).

19. Ramanan, R.N., Ling, T.C. and Ariff, A.B. 2008. The performance of a glass bead shaking technique for the disruption of Escherichia coli cells. Biotechnology and Bioprocess Engineering, 13(5): 613-623.

20. Rosa Estela Quiroz-Castañeda and Jorge Luis Folch-Mallol. 2013. Hydrolysis of Biomass Mediated by Cellulases for the Production of Sugars, Sustainable Degradation of Lignocellulosic Biomass - Techniques, Applications and Commercialization, Dr. Anuj Chandel (Ed.).

21. Rosano, G.L. 2014. Recombinant protein expression in Escherichia coli: Advances and challenges Recombinant protein expression in Escherichia coli : advances and challenges, (July).

22. Sangaran, P. 2014. Degradation of Lignocellulose from Coconut Husk by Bacteria Isolated from Cow Dung and Termite Gut. MSU Bachelors Thesis.

23. Sarker, P.K., Talukdar, S.A., Deb, P. and Sayem, S.M.A. 2013. Optimization and partial characterization of culture conditions for the production of alkaline protease from Bacillus licheniformis P003, (October).

24. Singh, R., Kumar, M., Mittal, A. and Kumar, P. 2016. Microbial enzymes : industrial progress in $21^{\text {st }}$ century. 3 Biotech, 6(2): 1-15.

25. Smith, P.K. et al. 1985. "Measurement of protein using bicinchoninic acid”. Anal. Biochem., 150(1): 76-85. 
26. Sweeney, M.D. and Xu, F. 2012. Biomass Converting Enzymes as Industrial Biocatalysts for Fuels and Chemicals: Recent Developments. Catalysts, 2(2): 244-263.

27. SwissProt. 2019. Retrieved from https://www.uniprot.org/.

28. Tamayo, C., Guerrero-prieto, V., Guigon-lopez, C., Vargas-albores, F., Acosta-muniz, C. and Ojedabarrios, D. 2016. Research \& Reviews : Journal of Botanical Sciences Oleophila for the Biocontrol of Penicillium expansum, 5(1): 38-45.

29. Xie, C., Yan, L., Gong, W., Zhu, Z., Tan, S. and Chen, D. 2016. Effects of Different Substrates on Lignocellulosic Enzyme Expression, Enzyme Activity and Substrate Utilization (Pleurotus eryngii), 410205, 1479-1494. 
